Check for updates

Cite this: RSC Adv., 2021, 11, 296

Received 15th September 2020

Accepted 24th November 2020

DOI: 10.1039/d0ra07893j

rsc.li/rsc-advances

\section{Oxygen doped graphitic carbon nitride nanosheets for the degradation of organic pollutants by activating hydrogen peroxide in the presence of bicarbonate in the dark $\uparrow$}

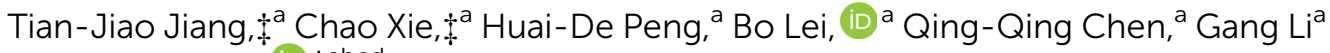 \\ and Cai-Wu Luo (D)*abcd
}

\begin{abstract}
The development of novel wastewater treatment processes that use heterogeneous catalysts to activate hydrogen peroxide $\left(\mathrm{H}_{2} \mathrm{O}_{2}\right)$ with bicarbonate $\left(\mathrm{HCO}_{3}^{-}\right)$has been a subject of great interest in recent years; however, significant challenges remain, despite research into numerous metal-based catalysts. The work presented herein employed oxygen-doped graphitic carbon nitride $\left(\mathrm{O} / \mathrm{g}-\mathrm{C}_{3} \mathrm{~N}_{4}\right)$ as a non-metal catalyst for activating $\mathrm{H}_{2} \mathrm{O}_{2}$ in the presence of $\mathrm{HCO}_{3}{ }^{-}$, and this method represented the first system capable of removing organic pollutants in the dark, to our knowledge. The catalysts were characterized using several microscopic imaging, spectroscopic, electrochemical, and crystallographic techniques, as well as $\mathrm{N}_{2}$-physorption procedures. Analysis of the results revealed that the $\mathrm{O} / \mathrm{g}-\mathrm{C}_{3} \mathrm{~N}_{4}$ catalyst possessed a high specific surface area and many defect sites. Various operational parameters, including the relative amounts of $\mathrm{HCO}_{3}^{-}, \mathrm{H}_{2} \mathrm{O}_{2}$, and $\mathrm{O} / \mathrm{g}-\mathrm{C}_{3} \mathrm{~N}_{4}$, were systemically investigated. A clear performance enhancement was observed in the degradation of organic contaminants when subjected to the $\mathrm{HCO}_{3}{ }^{-}-$ $\mathrm{H}_{2} \mathrm{O}_{2}-\mathrm{O} / \mathrm{g}-\mathrm{C}_{3} \mathrm{~N}_{4}$ system, and this result was ascribed to the synchronous adsorption and chemical oxidation processes. The novel system presented herein represented a new water treatment technology that was effective for removing organic contaminants.
\end{abstract}

\section{Introduction}

The bicarbonate anion, $\mathrm{HCO}_{3}{ }^{-}$, is relatively nontoxic and is common in natural water ecosystems. ${ }^{1}$ For example, its concentration is known to reach $50-200 \mathrm{ppm}$ in biological systems, and it may be presented at 14.7-25 mM in humans. It is worthwhile to note that $\mathrm{HCO}_{3}{ }^{-}$is always generated from $\mathrm{CO}_{2}$ as a main product of advanced oxidation processes, which are typically impractical for certain applications. Directly introducing $\mathrm{HCO}_{3}{ }^{-}$into a solution containing $\mathrm{H}_{2} \mathrm{O}_{2}$ often inhibits the degradation reaction; however, a few cases demonstrate that this process can promote the removal of organic pollutants. ${ }^{2-11}$ Despite this promising result, the huge required dosage is one of the main challenges associated with this approach because it

${ }^{a}$ School of Resource Environmental and Safety Engineering, University of South China, 421000, China. E-mail: luocaiwuo0@126.com; Tel: +86-734-8282345

${ }^{b}$ State Key Laboratory of Safety and Health for Metal Mines, Sinosteel Maanshan General Institute of Mining Research Co., Ltd, 243000, China

'Key Laboratory of Clean Energy Material, LongYan University, 364012, China

${ }^{d}$ Research Center for Eco-Environmental Sciences, Chinese Academy of Sciences, 100085, China

$\dagger$ Electronic supplementary information (ESI) available. See DOI: 10.1039/d0ra07893j

\$ They contributed equally to this work. significantly increases the cost of the treatment. To reduce this input cost, various transition metal ions, such as cobalt(III) ${ }^{12-18}$ and copper(II), ${ }^{19,20}$ have been tested as homogeneous catalysts. The results of those studies demonstrate that such metal catalysts accelerate the degradation of organic pollutants and distinctly reduce the required concentrations of $\mathrm{HCO}_{3}{ }^{-}$and $\mathrm{H}_{2} \mathrm{O}_{2}$. However, it is extremely difficult to recover the catalyst from the product solution, which is a significant drawback of this approach. As an alternative, various heterogeneous catalysts have been carefully developed to avoid such problems. To date, these systems have involved metal-based materials, such as Co-based ${ }^{21-25}$ and Cu-based catalysts. ${ }^{26-28}$ For example, Guo et al. ${ }^{23}$ reported an S-modified $\mathrm{CoFe}_{2} \mathrm{O}_{4}$ catalyst, which degraded acid orange II in a reactive system containing $\mathrm{HCO}_{3}{ }^{-}$and $\mathrm{H}_{2} \mathrm{O}_{2}$. Similarly, Pi et al. ${ }^{25}$ showed that their $\mathrm{Co}_{x} \mathrm{Mn}_{3-x} \mathrm{O}_{4}$ material was an effective catalyst for removing chlorophenols in the presence of a naturally-occurring concentration of $\mathrm{HCO}_{3}{ }^{-}$. Despite these advances, the leaching of toxic metal ions must be confronted during these reactions, because this phenomenon easily caused a second contamination and may reduce the stability of the catalyst. Therefore, other useful strategies have been explored..$^{29,30}$ For example, Pétrier et al..$^{29}$ adopted sonochemical technology to enhance the degradation of bisphenol in the presence of $\mathrm{HCO}_{3}{ }^{-}$. However, the required complex equipment 
input increased the cost. Therefore, in order to replace metalbased heterogeneous methods, there is a pressing need to develop simple non-metal-based heterogeneous catalysts that are inexpensive and green, and have excellent activity in combination with $\mathrm{H}_{2} \mathrm{O}_{2}$ and $\mathrm{HCO}_{3}{ }^{-}$.

Among non-metal heterogeneous catalysts, graphitic carbon nitride is an advantageous choice because it is safety, low cost, and has high stability. Importantly, it exhibits excellent catalytic performance under visible light illumination. Therefore, this type of catalyst has been applied for various purposes, including hydrogen production, ${ }^{31-34}$ but there are limited reports describing its activity for dark Fenton-like reaction. Cui et al. ${ }^{32}$ reported the degradation of organic dyes using $g-\mathrm{C}_{3} \mathrm{~N}_{4}$ in the presence of $\mathrm{H}_{2} \mathrm{O}_{2}$; however, this system showed hardly any catalytic activity in the dark. To attain the aforementioned target activity, it is necessary to first explore the catalytic sites in g- $\mathrm{C}_{3} \mathrm{~N}_{4}$ to evaluate $\mathrm{H}_{2} \mathrm{O}_{2}$ decomposition into reactive oxygen species (ROS). In general, this type of catalyst is characterized by extremely low specific surface area, which plays a vital role in the adsorption of organic pollutants. This factor significantly hinders the broad application of such catalysts in industry. To overcome this challenge, our group ${ }^{34}$ developed a novel g- $\mathrm{C}_{3} \mathrm{~N}_{4}$ catalyst using oxygen modification. This $\mathrm{O} / \mathrm{g}-\mathrm{C}_{3} \mathrm{~N}_{4}$ material possessed a huge specific surface area and exhibited some catalytic activity for the dark Fenton-like reaction. To further improve its catalytic performance, further system modification is necessary. As mentioned above, it can be expected that introducing $\mathrm{HCO}_{3}{ }^{-}$to the system should strengthen its capability to degrade organic pollutants in wastewater. This modification creates a weakly alkaline environment, which is favorable for decomposing $\mathrm{H}_{2} \mathrm{O}_{2}$ into ROS. ${ }^{21}$ However, it may generate new radicals, such as $\mathrm{CO}_{3}{ }^{-}$. The surface of $\mathrm{g}-\mathrm{C}_{3} \mathrm{~N}_{4}$ has a negative charge under near-alkaline conditions; therefore, it generates a counteracting force whereby $\mathrm{HCO}_{3}{ }^{-}$leaves the surface of the catalyst, thus inevitably capturing ROS, such as ${ }^{\circ} \mathrm{OH}$ radicals. Once the ${ }^{\circ} \mathrm{OH}$ radicals enter the solution, they are immediately captured by $\mathrm{HCO}_{3}{ }^{-}$to produce $\mathrm{CO}_{3}{ }^{-}$radicals, which have a longer lifetime. A literature survey ${ }^{35,36}$ confirmed that $\mathrm{CO}_{3}{ }^{-}$- radicals could directly remove organic pollutants. Still, the relationships between the specific surface area, nitrogen defective sites, and catalytic activity must be further elucidated, especially in terms of the dark Fenton-like reaction.

Herein, we describe a novel treatment technique for removing organic pollutants during dark Fenton-like reaction. To our knowledge, this is the first time that $\mathrm{O} / \mathrm{g}-\mathrm{C}_{3} \mathrm{~N}_{4}$ has been used as a heterogeneous catalyst in a system containing $\mathrm{HCO}_{3}{ }^{-}$ and $\mathrm{H}_{2} \mathrm{O}_{2}$. Various factors, including the specific surface area and nitrogen defective sites, are systemically studied and discussed in terms of how they influence the overall catalytic activity. A clear enhancement in organic pollutant degradation is observed using this novel system.

\section{Experimental}

\subsection{Materials and reagents}

All chemical reagents were purchased with analytical purity and used without any further purification. Deionized water (resistivity 18.2 M $\Omega$ ) was filtered using a Millipore Milli-Q water purification system.

\subsection{Preparation of $\mathrm{O} / \mathrm{g}-\mathrm{C}_{3} \mathrm{~N}_{4}$ catalyst}

The synthesis of the $\mathrm{O} / \mathrm{g}-\mathrm{C}_{3} \mathrm{~N}_{4}$ catalyst has been reported previously by our group. ${ }^{34}$ Specifically, melamine powder was placed in a crucible with a cover, and then calcinated in a static air atmosphere at $550{ }^{\circ} \mathrm{C}$ for $4 \mathrm{~h}$. The obtained yellow sample was denoted as $\mathrm{g}-\mathrm{C}_{3} \mathrm{~N}_{4}$. This $\mathrm{g}-\mathrm{C}_{3} \mathrm{~N}_{4}$ was added to deionized water, then transferred into a Teflon-sealed autoclave and maintained at $180^{\circ} \mathrm{C}$ for $4 \mathrm{~h}$. After cooling to room temperature, the obtained sample was washed with more deionized water and dried. Finally, the dried sample was placed in a crucible with a cover and calcinated for $4 \mathrm{~h}$ at different temperatures $\left(350,450\right.$, and $\left.550{ }^{\circ} \mathrm{C}\right)$ in a static air atmosphere. The resulting samples were denoted as $\mathrm{O} / \mathrm{g}-\mathrm{C}_{3} \mathrm{~N}_{4}-T$ (where $T=350,450$, or 550 ${ }^{\circ} \mathrm{C}$ ). Unless otherwise stated, the sample at $550{ }^{\circ} \mathrm{C}$ was denoted as simply, $\mathrm{O} / \mathrm{g}-\mathrm{C}_{3} \mathrm{~N}_{4}$. Additionally, the $\mathrm{Na}-\mathrm{O} / \mathrm{g}-\mathrm{C}_{3} \mathrm{~N}_{4}$ variant was synthesized using a wet impregnation method. Essentially, the $\mathrm{O} / \mathrm{g}-\mathrm{C}_{3} \mathrm{~N}_{4}$ catalyst was added to a solution containing $\mathrm{NaHCO}_{3}$, which was stirred vigorously for $24 \mathrm{~h}$ at room temperature. Next, they were dried. Finally, the sample was placed in a crucible with a cover, and calcinated for $4 \mathrm{~h}$ at $300{ }^{\circ} \mathrm{C}$ in a static air atmosphere (the theory value of $\mathrm{Na}^{+}$is $10 \mathrm{wt} \%$ ).

\subsection{Characterization}

X-ray diffraction (XRD) spectroscopy was carried out with a Bruker D8-Advance X-ray diffraction instrument; $\mathrm{N}_{2}$-physisorption was conducted on a Quantachrome Autosorb-1 instrument at liquid- $\mathrm{N}_{2}$ temperature; scanning electron microscopy (SEM) was carried out on a JEOL JSM $6700 \mathrm{~F}$ operating at an accelerating voltage of $10 \mathrm{kV}$; transmission electron microscope (TEM) was conducted on TALOS F200 X instrument operating at an accelerating voltage of $200 \mathrm{kV}$; electron paramagnetic resonance (EPR) was conducted on Bruker A300; X-ray photoelectron spectra (XPS) was examined on Thermo Fisher Scientific using $\mathrm{Al} K \alpha$; zeta potential was carried out on Zetasizer Nano ZSP instrument.

\subsection{Degradation of organic pollutants in the dark and under illumination}

The degradation reactions were performed in a flask at $25^{\circ} \mathrm{C}$, at atmospheric pressure. The reaction solution contained a certain amount of catalyst, $\mathrm{NaHCO}_{3}, \mathrm{H}_{2} \mathrm{O}_{2}$, and organic pollutants. The reaction mixture was stirred vigorously in the dark unless otherwise stated. For the photocatalytic reactions, the reaction mixture was placed under LED illumination, using all other reaction conditions identical to the experiments conducted in the dark (i.e., same catalyst dosages and concentrations of $\mathrm{H}_{2} \mathrm{O}_{2}$ and $\mathrm{HCO}_{3}{ }^{-}$). In all cases, a certain aliquot of each reaction solution was extracted at fixed intervals and then separated. The liquid was collected, and they were analyzed using a UV-vis spectrophotometer to quantify the concentration of residual organic pollutants. 


\section{Results and discussion}

\subsection{Characterization}

Fig. 1 displayed the XRD patterns of the $\mathrm{g}-\mathrm{C}_{3} \mathrm{~N}_{4}$ and $\mathrm{O} / \mathrm{g}-\mathrm{C}_{3} \mathrm{~N}_{4}$ catalysts. The diffraction peaks at $2 \theta=13.0^{\circ}$ and $27.5^{\circ}$ were observed for the $\mathrm{g}-\mathrm{C}_{3} \mathrm{~N}_{4}$ species, and these were assigned to the repeating tri-s-triazine units within the $\mathrm{g}-\mathrm{C}_{3} \mathrm{~N}_{4}$ unit layer (100), and the inter-planar stacking of unit layers (002), ${ }^{32}$ respectively. Besides the characteristic peaks associated with $\mathrm{g}-\mathrm{C}_{3} \mathrm{~N}_{4}$, the $\mathrm{O} / \mathrm{g}$ $\mathrm{C}_{3} \mathrm{~N}_{4}$ catalyst didn't exhibit any diffraction peaks corresponding to other phases, indicating that the original structure of $g-\mathrm{C}_{3} \mathrm{~N}_{4}$ was largely retained following the oxygen modification. However, the strongest diffraction peaks for the $\mathrm{O} / \mathrm{g}-\mathrm{C}_{3} \mathrm{~N}_{4}$ catalyst shifted toward higher angles (i.e., toward $2 \theta=27.8^{\circ}$ ), relative to those observed for $\mathrm{g}-\mathrm{C}_{3} \mathrm{~N}_{4}$, representing the decreased distances within the layered structure. ${ }^{\mathbf{1 1}}$ This change was attributed to the doping effect of oxygen atoms and the resulting distortion of the graphite structure.

The images of the $\mathrm{g}-\mathrm{C}_{3} \mathrm{~N}_{4}$ and $\mathrm{O} / \mathrm{g}-\mathrm{C}_{3} \mathrm{~N}_{4}$ catalysts captured using SEM characterization were shown in Fig. S1. $\dagger$ It is clear from these images that the $\mathrm{g}-\mathrm{C}_{3} \mathrm{~N}_{4}$ catalyst contained agglomerated particles, and its surface appeared relatively rough. Compared to the bulk g- $\mathrm{C}_{3} \mathrm{~N}_{4}$, a cotton-like morphology was visible in the $\mathrm{O} / \mathrm{g}-\mathrm{C}_{3} \mathrm{~N}_{4}$ image. This is likely because the nanosheets of $\mathrm{g}-\mathrm{C}_{3} \mathrm{~N}_{4}$ were partially decomposed following the hydrothermal-calcination treatment. This difference was further confirmed through characterization using TEM characterization (Fig. S2 $\dagger$ ). Table $\mathrm{S} 1 \dagger$ listed the contents of carbon, nitrogen, and oxygen atoms, which were determined by elemental analysis of the $\mathrm{g}-\mathrm{C}_{3} \mathrm{~N}_{4}$ and $\mathrm{O} / \mathrm{g}-\mathrm{C}_{3} \mathrm{~N}_{4}$ samples from SEM characterization. It is observed that $\mathrm{O} / \mathrm{g}-\mathrm{C}_{3} \mathrm{~N}_{4}$ contained lower nitrogen atom content but a higher atomic ratio of carbon to nitrogen, relative to $\mathrm{g}-\mathrm{C}_{3} \mathrm{~N}_{4}$. These results indicated that delamination and depolymerization processes were happened, causing loss of nitrogen atoms and creation of nitrogen defect sites. To confirm the existence of such defect sites, EPR measurements were carried out, and the results were presented in Fig. S3. $\uparrow$ There were six large positive peaks observed in the

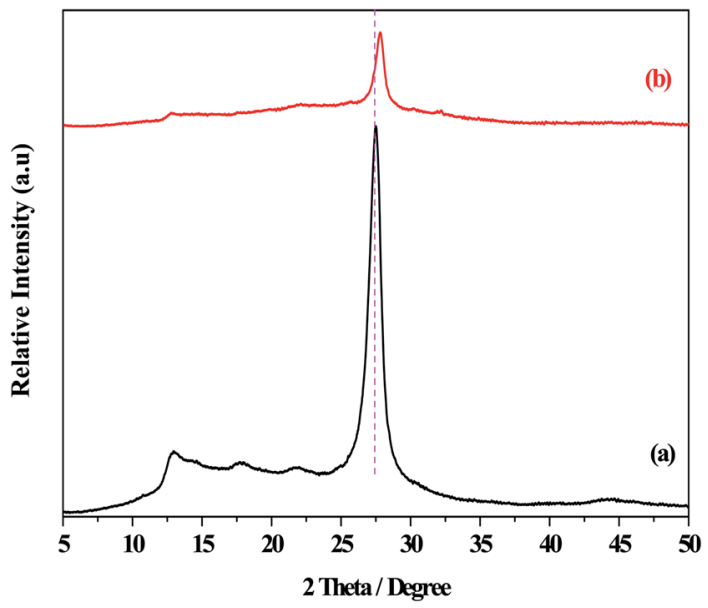

Fig. 1 The XRD patterns of different catalysts. (a) $\mathrm{g}-\mathrm{C}_{3} \mathrm{~N}_{4}$, (b) $\mathrm{O} / \mathrm{g}$ $\mathrm{C}_{3} \mathrm{~N}_{4}$. spectrum of the g- $\mathrm{C}_{3} \mathrm{~N}_{4}$ catalyst, but only four positive peaks in the $\mathrm{O} / \mathrm{g}-\mathrm{C}_{3} \mathrm{~N}_{4}$ catalyst's spectrum. These results suggested that the latter had a greater quantity of unpaired electrons than the former. This can be justified based on the fact that some nitrogen atoms have been removed and other nitrogen atoms were replaced by oxygen atoms, in agreement with the XRD and elemental analysis. The analysis of all of these results led to the conclusion that the nitrogen content, and especially the morphology, of $\mathrm{O} / \mathrm{g}-\mathrm{C}_{3} \mathrm{~N}_{4}$ was altered relative to those of $\mathrm{g}-\mathrm{C}_{3} \mathrm{~N}_{4}$.

The textural properties of $g-\mathrm{C}_{3} \mathrm{~N}_{4}$ and the series of $\mathrm{O} / \mathrm{g}-\mathrm{C}_{3} \mathrm{~N}_{4}-T$ catalysts, which were determined from $\mathrm{N}_{2}$ adsorption-desorption experiments, were compiled in Table 1 . Relative to the $\mathrm{g}$ $\mathrm{C}_{3} \mathrm{~N}_{4}$, and within the series of $\mathrm{O} / \mathrm{g}-\mathrm{C}_{3} \mathrm{~N}_{4}-T$ catalysts, the specific surface area $\left(S_{\mathrm{BET}}\right)$, first slightly increased and then increased remarkably, up to $>23$ times. Simultaneously, the total pore volume $\left(V_{\text {total }}\right)$ first increased, and then significantly increased, up to approximately 10 times. It is well-known that $\mathrm{g}-\mathrm{C}_{3} \mathrm{~N}_{4}$ produced from various precursors can be easily obtained via high-temperature calcination, but the resulting $S_{\mathrm{BET}}$ was typically below $10 \mathrm{~m}^{2} \mathrm{~g}^{-1}$. This is because the interactions between the layers of $\mathrm{g}-\mathrm{C}_{3} \mathrm{~N}_{4}$ were too strong, owing to the van der Waals forces and/or hydrogen bonds in the material, which led to serious aggregation of the particles. After the hydrothermal treatment, these interactions were weakened due to the attacks from water molecules at high temperature and pressure. The resulting exposed nanosheets were further attacked by oxygen during the high-temperature calcination, thus creating a new morphology and increasing the $S_{\mathrm{BET}}$. Based on the SEM, TEM, and pore size distribution results (see Fig. $\mathbf{S} 4 \dagger$ ), we determined that the increased $S_{\mathrm{BET}}$ was mainly attributed to the change in the morphology of the catalyst. In general, the large $S_{\mathrm{BET}}$ is an important factor for strengthening catalytic performance, because this represents a greater proportion of exposed adsorption and catalytic active sites.

Fig. 2 displayed the binding energies of the $\mathrm{N}$ 1s in $\mathrm{g}-\mathrm{C}_{3} \mathrm{~N}_{4}$ and the series of $\mathrm{O} / \mathrm{g}-\mathrm{C}_{3} \mathrm{~N}_{4}-T$ samples, which were determined based on XPS. In the bulk $\mathrm{g}-\mathrm{C}_{3} \mathrm{~N}_{4}$, four different peaks at 398.9, $399.8,401.5$, and $404.6 \mathrm{eV}$ were observed, corresponding to the $\mathrm{sp}^{2}$-hybridized nitrogen $\left(\mathrm{N}-\mathrm{C}=\mathrm{N}\right.$; denoted as $\left.\mathrm{sp}^{2}(\mathrm{~N})\right)$, the $\mathrm{sp}^{3}$ hybridized nitrogen $\left(\mathrm{N}-[\mathrm{C}]_{3}\right.$; denoted as $\left.\mathrm{sp}^{3}(\mathrm{~N})\right)$, the $\mathrm{N}-\mathrm{H}$ bonds, and the $\pi$ band localized in heterocycles, respectively. ${ }^{10,11,14-18}$ The $\mathrm{N}$ 1s spectra associated with the series of $\mathrm{O} / \mathrm{g}-\mathrm{C}_{3} \mathrm{~N}_{4}-T$ samples contained similar peaks to the bulk $\mathrm{g}-\mathrm{C}_{3} \mathrm{~N}_{4}$. However, the ratio of $\mathrm{sp}^{2}(\mathrm{~N})$ to $\mathrm{sp}^{3}(\mathrm{~N})$ first increased (see Table $\mathrm{S} 2 \dagger$ ) and then decreased with increasing temperature in the $\mathrm{O} / \mathrm{g}-\mathrm{C}_{3} \mathrm{~N}_{4}-T$ series (i.e., $350{ }^{\circ} \mathrm{C} v$ s. $450{ }^{\circ} \mathrm{C}$ vs. $550{ }^{\circ} \mathrm{C}$ ), and as compared to g-

Table 1 Results of textural properties of various catalysts ${ }^{a}$

\begin{tabular}{lcl}
\hline Catalysts & $S_{\text {BET }}\left(\mathrm{m}^{2} \mathrm{~g}^{-1}\right)$ & $V_{\text {total }}\left(\mathrm{cc} \mathrm{g}^{-1}\right)$ \\
\hline $\mathrm{g}-\mathrm{C}_{3} \mathrm{~N}_{4}$ & 11.5 & 0.0693 \\
$\mathrm{O} / \mathrm{g}-\mathrm{C}_{3} \mathrm{~N}_{4}-350^{\circ} \mathrm{C}$ & 42.2 & 0.3056 \\
$\mathrm{O} / \mathrm{g}-\mathrm{C}_{3} \mathrm{~N}_{4}-450^{\circ} \mathrm{C}$ & 50.7 & 0.3107 \\
$\mathrm{O} / \mathrm{g}-\mathrm{C}_{3} \mathrm{~N}_{4}-550{ }^{\circ} \mathrm{C}$ & 236.4 & 0.6344
\end{tabular}

${ }^{a} S_{\mathrm{BET}}$ was denoted as the specific surface area; $V_{\text {total }}$ was denoted as the total pore volume. 


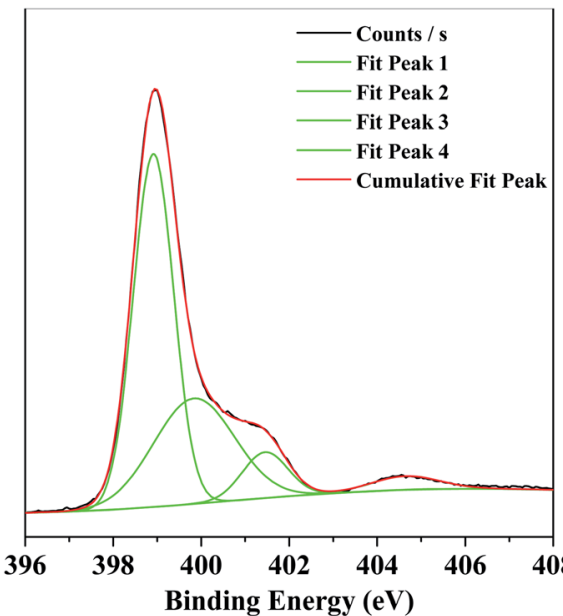

(a)

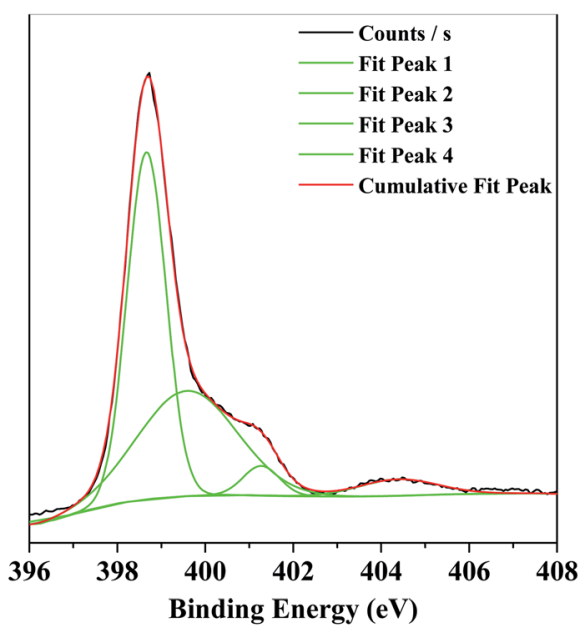

(c)

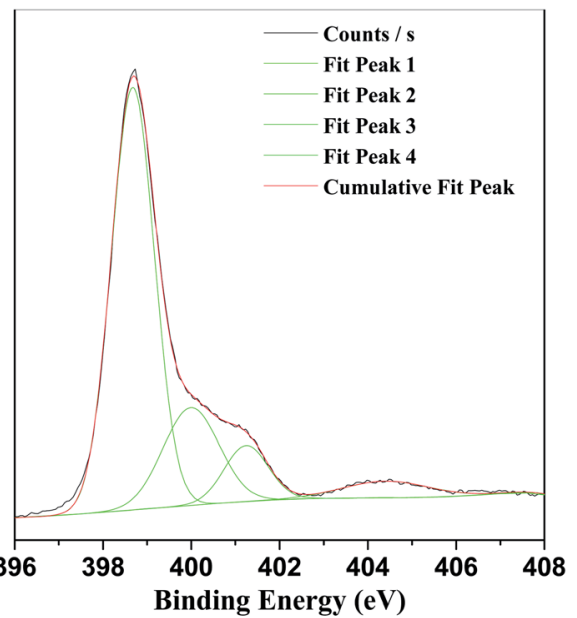

(b)

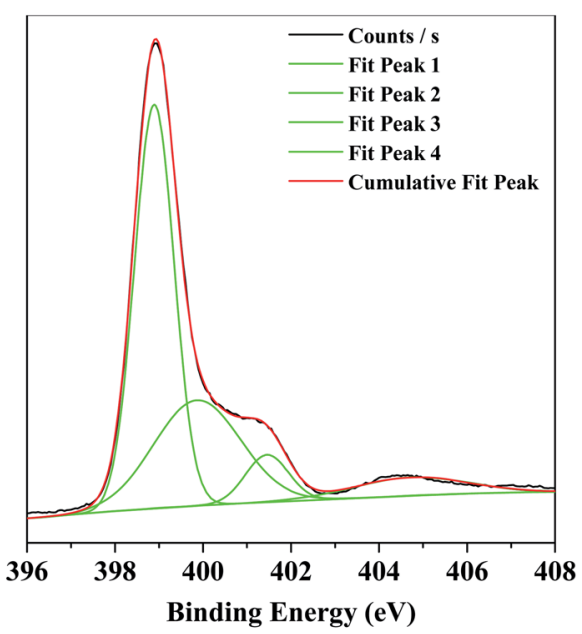

(d)

Fig. 2 The XPS characterization for $\mathrm{N}$ 1s of various catalysts. (a) $\mathrm{g}-\mathrm{C}_{3} \mathrm{~N}_{4}$, (b) $\mathrm{O} / \mathrm{g}-\mathrm{C}_{3} \mathrm{~N}_{4}-350{ }^{\circ} \mathrm{C}$, (c) $\mathrm{O} / \mathrm{g}-\mathrm{C}_{3} \mathrm{~N}_{4}-450{ }^{\circ} \mathrm{C}$, (d) $\mathrm{O} / \mathrm{g}-\mathrm{C}_{3} \mathrm{~N}_{4}-550{ }^{\circ} \mathrm{C}$.

$\mathrm{C}_{3} \mathrm{~N}_{4}$. This result illustrated that loss of $\mathrm{N}$ occurred preferentially, thus forming some nitrogen defect sites.

\subsection{Degradation of organic pollutants under different reaction conditions}

3.2.1. Operational parameters for organic pollutant degradation. A key process involved in enhancing the catalytic activity of $\mathrm{O} / \mathrm{g}-\mathrm{C}_{3} \mathrm{~N}_{4}$ catalysts within the $\mathrm{HCO}_{3}{ }^{-} / \mathrm{H}_{2} \mathrm{O}_{2}$ system, was the activation of $\mathrm{H}_{2} \mathrm{O}_{2}$ toward ROS. To verify this concept, degradation experiments were carried out using this system $(\mathrm{O} /$ g- $\mathrm{C}_{3} \mathrm{~N}_{4}+\mathrm{H}_{2} \mathrm{O}_{2}$ ), and the results were shown in Fig. S5. $\dagger$ One can see that the Rhodamine $\mathrm{B}$ (denoted as $\mathrm{RhB}$ ) degradation barely occurred only for $\mathrm{H}_{2} \mathrm{O}_{2}$ while it over the catalyst in the presence of $\mathrm{H}_{2} \mathrm{O}_{2}$ was completely degraded after $160 \mathrm{~h}$. A low catalyst loading parameter was selected to exclude the influence of adsorption (no more than 5\%), which further allowed the conclusion that the synergistic effect between $\mathrm{O} / \mathrm{g}-\mathrm{C}_{3} \mathrm{~N}_{4}$ and $\mathrm{H}_{2} \mathrm{O}_{2}$ induced significant removal of RhB. This result suggested that some ROS were indeed generated, and these species acted to eliminate organic pollutants. In other words, $\mathrm{O} / \mathrm{g}-\mathrm{C}_{3} \mathrm{~N}_{4}$ contained catalytic active sites, such as nitrogen defective sites, which promoted the activation of $\mathrm{H}_{2} \mathrm{O}_{2}$ toward ROS. However, the degradation rate of $\mathrm{RhB}$ was extremely slow under the experimental conditions. Therefore, a new strategy was implemented, in which $\mathrm{HCO}_{3}{ }^{-}$was introduced into the system containing $\mathrm{O} / \mathrm{g}-\mathrm{C}_{3} \mathrm{~N}_{4}$ and $\mathrm{H}_{2} \mathrm{O}_{2}$. The important reaction conditions were investigated in detail, and the relevant results were presented here.

(i) Effect of the $\mathrm{HCO}_{3}{ }^{-}$concentration. Fig. 3 illustrated the influence of the concentration of $\mathrm{HCO}_{3}{ }^{-}$on the outcome of the dark Fenton-like reaction. It is determined that the rate of $\mathrm{RhB}$ degradation in the reaction solution accelerated significantly following the addition of $\mathrm{HCO}_{3}{ }^{-}$. Moreover, the $\mathrm{RhB}$ degradation rate increased with increasing concentrations of $\mathrm{HCO}_{3}{ }^{-}$,

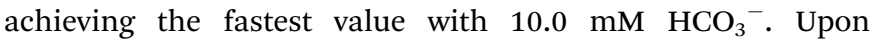
increasing the concentration of $\mathrm{HCO}_{3}{ }^{-}$even further, the 


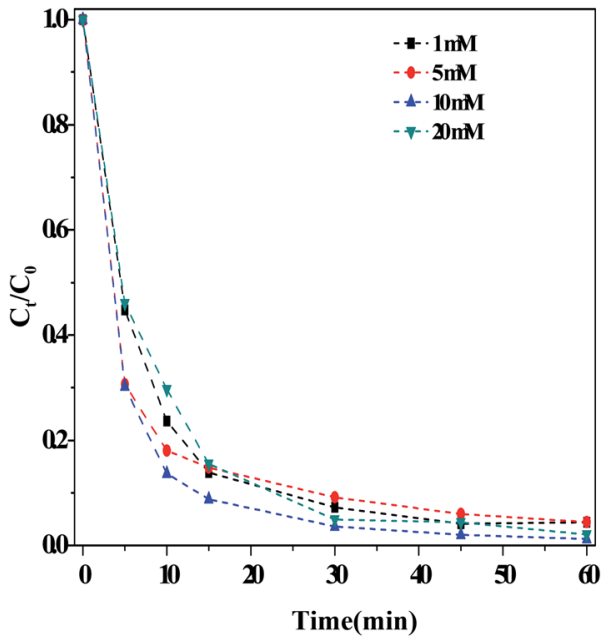

Fig. 3 Effect of the concentrations of $\mathrm{HCO}_{3}{ }^{-}$on the $\mathrm{RhB}$ degradation. Reaction conditions: $\left[\mathrm{H}_{2} \mathrm{O}_{2}\right]=36 \mathrm{mM},\left[\mathrm{O} / \mathrm{g}-\mathrm{C}_{3} \mathrm{~N}_{4}\right]=1.0 \mathrm{~g} \mathrm{~L}^{-1},[\mathrm{RhB}]=$ $10 \mathrm{mg} \mathrm{L}^{-1}, 25^{\circ} \mathrm{C}$ and $60 \mathrm{~min}$.

degradation rate was reduced, although it remained prominently higher than that measured in the absence of $\mathrm{HCO}_{3}{ }^{-}$(i.e., when $\left[\mathrm{HCO}_{3}{ }^{-}\right]>10 \mathrm{mM}$, the reaction rate was still enhanced). These results showed that the concentration range for $\mathrm{HCO}_{3}{ }^{-}$ was very broad under these experimental conditions. Literature reports ${ }^{16,19}$ demonstrated that the impact of $\mathrm{HCO}_{3}{ }^{-}$concentration on the organic pollutant degradation varied depending on the system. For example, Cheng et al. ${ }^{19}$ found that the degradation of acid orange II using a $\mathrm{Cu}(\mathrm{II})-\mathrm{H}_{2} \mathrm{O}_{2}$ system was restrained when the concentration of $\mathrm{HCO}_{3}{ }^{-}$was greater than $5 \mathrm{mM}$. This indicated that another reaction may have taken place in solution, besides that involving the catalyst. Surprisingly, the solution $\mathrm{pH}$ was found to increase slightly $(\sim 1.0 \mathrm{pH}$ unit) after the reaction, as shown in Fig. S6. $\dagger$ Lei et al..$^{28}$ observed the same phenomenon in their catalytic system containing a mixture of $\mathrm{CuO}-\mathrm{FeO}$ and persulfate. According to eqn (1)-(6), singlet oxygen species can be obtained on the basis of $\mathrm{pH}$ changes after the reaction.

$$
\begin{gathered}
\mathrm{HCO}_{3}^{-{ }^{-}+} \mathrm{OH} \rightarrow \mathrm{CO}_{3}^{\cdot-}+\mathrm{H}_{2} \mathrm{O} \\
\mathrm{CO}_{3}{ }^{--}+\mathrm{H}_{2} \mathrm{O}_{2} \rightarrow \mathrm{HCO}_{3}^{-{ }^{-}} \mathrm{OOH} \\
\cdot \mathrm{OOH} \rightarrow \mathrm{H}^{+}+\mathrm{O}_{2}{ }^{--} \\
\mathrm{O}_{2}^{\cdot-}+{ }^{\cdot} \mathrm{OH} \rightarrow{ }^{1} \mathrm{O}_{2}+\mathrm{OH}^{-} \\
\mathrm{O}_{2}{ }^{\cdot-}+{ }^{\cdot} \mathrm{OOH} \rightarrow{ }^{1} \mathrm{O}_{2}+\mathrm{OOH}^{-} \\
\cdot \mathrm{OOH}+{ }^{\cdot} \mathrm{OOH} \rightarrow{ }^{1} \mathrm{O}_{2}+\mathrm{H}_{2} \mathrm{O}_{2}
\end{gathered}
$$

(ii) Effect of the $\mathrm{H}_{2} \mathrm{O}_{2}$ concentration. Fig. 4 depicted the influence of the concentration of $\mathrm{H}_{2} \mathrm{O}_{2}$ on the dark Fenton-like reaction. It is clear that the $\mathrm{RhB}$ degradation efficiency increased with increasing concentrations of $\mathrm{H}_{2} \mathrm{O}_{2}$, arriving at a maximum rate when $\left[\mathrm{H}_{2} \mathrm{O}_{2}\right]=15 \mathrm{mM}$. Increasing the $\mathrm{H}_{2} \mathrm{O}_{2}$

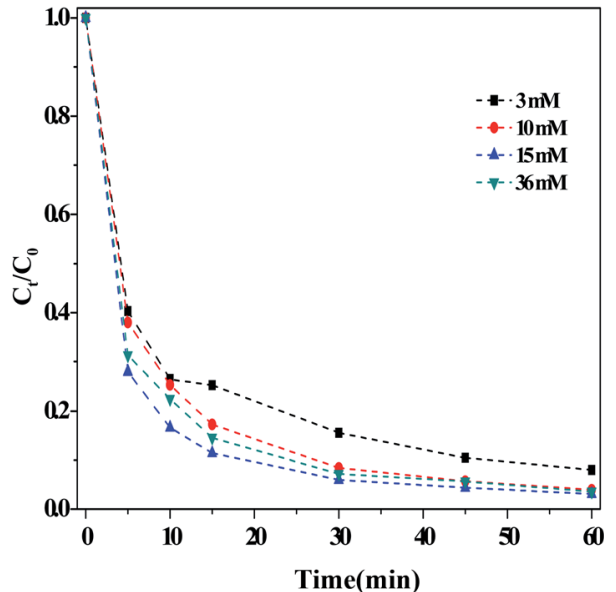

Fig. 4 Effect of the concentration of $\mathrm{H}_{2} \mathrm{O}_{2}$ on the RhB degradation. Reaction conditions: $\left[\mathrm{HCO}_{3}\right]=10 \mathrm{mM},\left[\mathrm{O} / \mathrm{g}-\mathrm{C}_{3} \mathrm{~N}_{4}\right]=1.0 \mathrm{~g} \mathrm{~L}^{-1},[\mathrm{RhB}]=$ $10 \mathrm{mg} \mathrm{L}^{-1}, 25^{\circ} \mathrm{C}, \mathrm{pH} \approx 8.4$ and $60 \mathrm{~min}$.

concentration further did not lead to any change in the efficiency of RhB degradation. As mentioned above, the ROS were generated from the decomposition of $\mathrm{H}_{2} \mathrm{O}_{2}$, so it followed that, when the concentration of $\mathrm{H}_{2} \mathrm{O}_{2}$ was relatively lower, fewer ROS could be formed. Therefore, by increasing the concentration of $\mathrm{H}_{2} \mathrm{O}_{2}$, the efficiency of $\mathrm{RhB}$ degradation was enhanced. However, the $\mathrm{H}_{2} \mathrm{O}_{2}$ concentration was increased further, the negligible influence on the $\mathrm{RhB}$ degradation indicated that the overall reaction predominately relied on the action of the catalyst.

(iii) Effect of the $\mathrm{O} / \mathrm{g}-\mathrm{C}_{3} \mathrm{~N}_{4}$ catalyst. Fig. 5 illustrated the impact of the $\mathrm{O} / \mathrm{g}-\mathrm{C}_{3} \mathrm{~N}_{4}$ catalyst on RhB degradation in the dark Fentonlike reaction. The degradation of RhB clearly increased with increasing catalyst loading, reaching a maximum value at a catalyst concentration of $0.8 \mathrm{~g} \mathrm{~L}^{-1}$. The rate remained stable when additional catalyst was added. It is evident that the removal of $\mathrm{RhB}$ was closely related to the catalyst dosage, as shown in Fig. S7. $\dagger$ This is because a larger quantity of catalyst

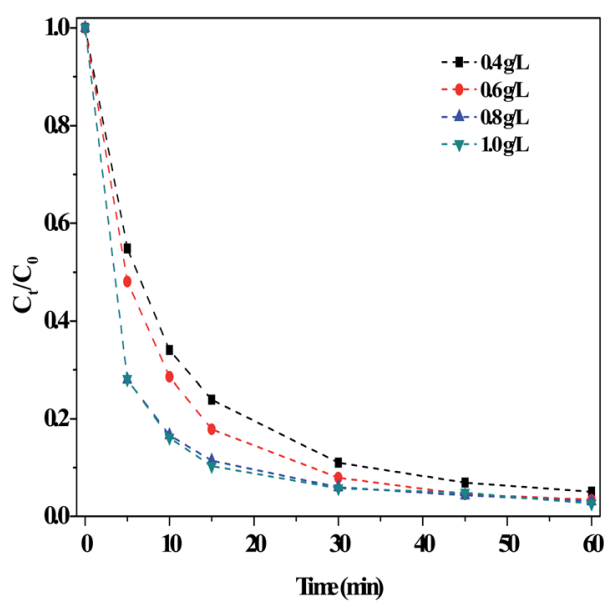

Fig. 5 Effect of the usages of $\mathrm{O} / \mathrm{g}-\mathrm{C}_{3} \mathrm{~N}_{4}$ on the RhB degradation. Reaction conditions: $\left[\mathrm{NaHCO}_{3}\right]=15 \mathrm{mM},\left[\mathrm{H}_{2} \mathrm{O}_{2}\right]=10 \mathrm{mM},[\mathrm{RhB}]=$ $10 \mathrm{mg} \mathrm{L}^{-1}, 25^{\circ} \mathrm{C}, \mathrm{pH} \approx 8.4$ and $60 \mathrm{~min}$. 
offered more adsorption sites, thus enabling more RhB removal. However, addition of too much catalyst led to agglomeration and increased counter forces between the particles, ultimately reducing RhB adsorption. In contrast, an insufficient amount of catalyst was introduced, there would not have enough available sites to activate $\mathrm{H}_{2} \mathrm{O}_{2}$ for producing ROS, so the RhB degradation rate stabilized or may decrease slightly.

Based on the described systematic screening experiments, the optimal reaction conditions were determined: $\left[\mathrm{NaHCO}_{3}\right]=$ $10 \mathrm{mM},\left[\mathrm{H}_{2} \mathrm{O}_{2}\right]=15 \mathrm{mM}$, and $\left[\mathrm{O} / \mathrm{g}-\mathrm{C}_{3} \mathrm{~N}_{4}\right]=0.8 \mathrm{~g} \mathrm{~L}^{-1}$. Applying these conditions, other important parameters were investigated.

Fig. S8† showed the influence of metal ions (with $\mathrm{Cl}^{-}$as the counter anion) on RhB degradation in the dark Fenton-like reaction. Based on this figure, there appeared to be no clear difference in RhB degradation among the tested metal ions, indicating that these ions had no appreciable effect on the RhB degradation reaction. This is because they were not involved the catalytic reaction, but rather, only impact solubility. For example, $\mathrm{Ca}^{2+}$ decreased the solubility of reaction solution, resulting in a decreased concentration of $\mathrm{HCO}_{3}{ }^{-}$. Many previous studies ${ }^{\mathbf{1 2 - 1 9}}$ demonstrated that certain transition metal ions, such as $\mathrm{Co}(\mathrm{II})$ and $\mathrm{Cu}(\mathrm{II})$, effectively degraded organic pollutants due to the formation of $\mathrm{M}\left[\mathrm{HCO}_{3}{ }^{-}-\mathrm{H}_{2} \mathrm{O}_{2}\right]_{2} \mathrm{RhB}$ complexes. These complexes were formed when, for example, $\mathrm{Co}^{2+}$ interacted with $\mathrm{HCO}_{3}{ }^{-}$to form a polymeric $\mathrm{M}^{n+}\left[\mathrm{HCO}_{3}{ }^{-}\right]$ species, which then adsorbed $\mathrm{H}_{2} \mathrm{O}_{2}$. As a result, the ${ }^{\circ} \mathrm{OH}$ radicals were immediately generated, and attacked the RhB molecules on the surface of the catalyst. These processes led to a remarkable enhancement in RhB degradation. In contrast to transition metal ions, the metal ions studied herein were widely distributed in natural water environments, and they did not form $\mathrm{M}$ $\left[\mathrm{HCO}_{3}{ }^{-}-\mathrm{H}_{2} \mathrm{O}_{2}\right]_{2} \mathrm{RhB}$ complexes. We additionally studied the influence of several anions (using $\mathrm{Na}^{+}$as the metal ion), and the results were displayed in Fig. S9. $\dagger$ It is determined that most anions, except for $\mathrm{CO}_{3}{ }^{-}$and $\mathrm{CH}_{3} \mathrm{COO}^{-}$, positively impacted the RhB degradation. These results demonstrated that the studied catalytic system was resilient in terms of metal ions and anions, so it represented great potential for applications in industry. The removal of other organic pollutants was also investigated, and the results were shown in Fig. S10. $\dagger$ All of the tested species were removed effectively using this system, further verifying that it was favorable for degrading various organic contaminants.

Fig. S11† displayed the impact of darkness versus LED illumination on the degradation of $\mathrm{RhB}$. It is evident that the system containing $\mathrm{O} / \mathrm{g}-\mathrm{C}_{3} \mathrm{~N}_{4}, \mathrm{HCO}_{3}{ }^{-}$, and $\mathrm{H}_{2} \mathrm{O}_{2}$ exhibited better catalytic activity under LED illumination, relative to in the dark. This is because additional light-induced reactions occurred simultaneously with the dark Fenton-like reaction, as described by eqn (7)-(9); these represented a typical photo-Fenton-like reaction process. Specifically, under LED light, the photogenerated hole $\left(\mathrm{h}^{+}\right)$directly reacted with $\mathrm{RhB}$, and the photogenerated electron $\left(\mathrm{e}^{-}\right)$interacted with the dissolved oxygen in aqueous solution to form the $\mathrm{O}_{2}{ }^{-}$species. These species could remove $\mathrm{RhB}$, so the degradation of $\mathrm{RhB}$ was enhanced under LED illumination. The results of these experiments clearly showed that this catalytic degradation process could proceed under both light and dark conditions. This is a particularly useful finding for this new non-metal catalytic system, which is capable of eliminating organic pollutants, thus reducing environmental contamination as much as possible. On the contrary, traditional carbon-based materials that promote Fenton-like reactions doesn't happen under light illumination, so the system developed herein clearly has an advantage in its ability to function in the dark.

$$
\begin{gathered}
\text { Catalyst }+h v \rightarrow \mathrm{h}^{+}+\mathrm{e}^{-} \\
\mathrm{O}_{2}+\mathrm{e}^{-} \rightarrow \mathrm{O}_{2}^{\cdot} \\
\mathrm{h}^{+}\left(\text {or } \mathrm{O}_{2}^{\cdot-}\right)+\text { organics } \rightarrow \mathrm{CO}_{2}+\mathrm{H}_{2} \mathrm{O}
\end{gathered}
$$

The stability of the $\mathrm{O} / \mathrm{g}-\mathrm{C}_{3} \mathrm{~N}_{4}$ catalyst was investigated, and the results were presented in Fig. 6. Cyclic RhB degradation experiments were conducted under dark conditions. Specifically, after the reaction, the catalyst was carefully washed with deionized water and ethanol, respectively, and then dried. Afterward, it was employed for the next cycle following the addition of a fresh reaction solution containing $\mathrm{HCO}_{3}{ }^{-}$and $\mathrm{H}_{2} \mathrm{O}_{2}$, wherein the concentration of these components remained the same as in the first reaction. As shown in Fig. 6, the RhB degradation rate hardly decreased, even after several reaction cycles, thereby verifying the high stability of the system and repeatability of the process.

The degradation of organic dyes in wastewater was completed using the system containing $\mathrm{HCO}_{3}{ }^{-}$and $\mathrm{H}_{2} \mathrm{O}_{2}$, and the results were compiled in Table 2. Based on these reactions, the $\mathrm{HCO}_{3}{ }^{-}$and $\mathrm{H}_{2} \mathrm{O}_{2}$ consumptions were significant in the absence of catalyst. When $\mathrm{Co}$ (II) or $\mathrm{Cu}$ (II) was added into the reaction solution, significant degradation of the organic dyes was always observed. The main drawbacks associated with these catalysts included their cost, high toxicity, and difficult

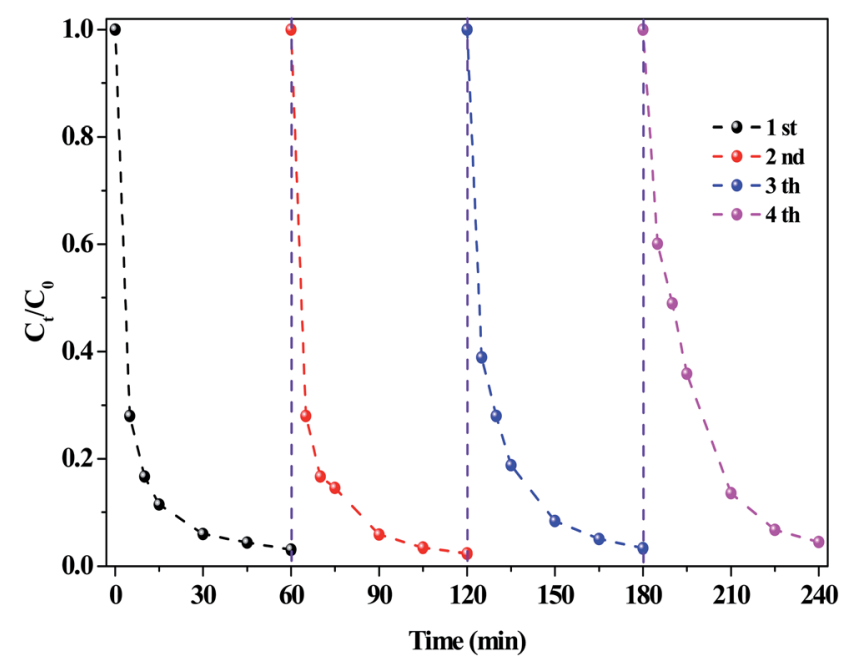

Fig. 6 The stability of catalysts on the $\mathrm{RhB}$ degradation. Reaction conditions: $\left[\mathrm{NaHCO}_{3}\right]=10 \mathrm{mM},\left[\mathrm{H}_{2} \mathrm{O}_{2}\right]=15 \mathrm{mM},\left[\mathrm{O} / \mathrm{g}-\mathrm{C}_{3} \mathrm{~N}_{4}\right]=0.8 \mathrm{~g}$ $\mathrm{L}^{-1},[\mathrm{RhB}]=10 \mathrm{mg} \mathrm{L}^{-1}, 25^{\circ} \mathrm{C}, \mathrm{pH} \approx 8.4$ and $60 \mathrm{~min}$. 
Table 2 The degradation of various organic dyes over kinds of catalysts in the presence of $\mathrm{H}_{2} \mathrm{O}_{2}$ and $\mathrm{NaHCO}_{3}$

\begin{tabular}{|c|c|c|c|c|}
\hline Catalysts & Organics & Reaction conditions & Degradation & Ref. \\
\hline No & MB, MO, RhB & $\mathrm{C}\left(\mathrm{H}_{2} \mathrm{O}_{2}\right)=0.1 \mathrm{M}, \mathrm{C}\left(\mathrm{NaHCO}_{3}\right)=0.5 \mathrm{M}$ & $\sim 100 \%, 300 \mathrm{~min}$ & 5 \\
\hline \multirow[t]{2}{*}{$\mathrm{Co}(\mathrm{II})$} & $\mathrm{MB}$ & $\mathrm{C}(\mathrm{Co}(\mathrm{II}))=20 \mu \mathrm{M}, \mathrm{C}\left(\mathrm{H}_{2} \mathrm{O}_{2}\right)=20 \mathrm{mM}, \mathrm{C}\left(\mathrm{NaHCO}_{3}\right)=25 \mathrm{mM}$ & $\sim 100 \%, \sim 50 \mathrm{~min}$ & 13 \\
\hline & $X-3 B$ & $\mathrm{C}(\mathrm{Co}(\mathrm{II}))=5 \mu \mathrm{M}, \mathrm{C}\left(\mathrm{H}_{2} \mathrm{O}_{2}\right)=4 \mathrm{mM}, \mathrm{C}\left(\mathrm{NaHCO}_{3}\right)=10 \mathrm{mM}$ & $>90 \%, 40 \mathrm{~min}$ & 16 \\
\hline $\mathrm{Cu}(\mathrm{II})$ & AOII & $\mathrm{C}(\mathrm{Cu}(\mathrm{II}))=0.03 \mathrm{mM}, \mathrm{C}\left(\mathrm{H}_{2} \mathrm{O}_{2}\right)=4 \mathrm{mM}, \mathrm{C}\left(\mathrm{NaHCO}_{3}\right)=10 \mathrm{mM}$ & $\sim 100 \%, 10 \mathrm{~min}$ & 19 \\
\hline $\begin{array}{l}\text { Diatomite- } \\
\text { supported cobalt }\end{array}$ & $\begin{array}{l}\text { MB } \\
\text { RhB }\end{array}$ & $\mathrm{C}($ Catal. $)=0.4 \mathrm{~g} \mathrm{~L}^{-1}, \mathrm{C}\left(\mathrm{H}_{2} \mathrm{O}_{2}\right)=60 \mathrm{mM}, \mathrm{C}\left(\mathrm{NaHCO}_{3}\right)=25 \mathrm{mM}$ & $\begin{array}{l}\sim 99 \%, 80 \mathrm{~min} \\
70 \%, 5 \mathrm{~h}\end{array}$ & 21 \\
\hline $\mathrm{S} / \mathrm{CoFe}_{2} \mathrm{O}_{4}$ & AOII & $\mathrm{C}($ Catal. $)=0.1 \mathrm{~g} \mathrm{~L}^{-1}, \mathrm{C}\left(\mathrm{H}_{2} \mathrm{O}_{2}\right)=3 \mathrm{mM}, \mathrm{C}\left(\mathrm{NaHCO}_{3}\right)=0.1 \mathrm{~g} \mathrm{~L}^{-1}$ & $\sim 99 \%, 15 \mathrm{~min}$ & 23 \\
\hline \multirow[t]{2}{*}{$\mathrm{O} / \mathrm{g}-\mathrm{C}_{3} \mathrm{~N}_{4}$} & $\begin{array}{l}\mathrm{RhB} \\
\mathrm{MB}\end{array}$ & $\mathrm{C}($ Catal. $)=0.8 \mathrm{~g} \mathrm{~L}^{-1}, \mathrm{C}\left(\mathrm{H}_{2} \mathrm{O}_{2}\right)=15 \mathrm{mM}, \mathrm{C}\left(\mathrm{NaHCO}_{3}\right)=10 \mathrm{mM}$ & $\begin{array}{l}\sim 90 \%, 15 \mathrm{~min} \\
>90 \%, 5 \mathrm{~min}\end{array}$ & \multirow[t]{2}{*}{$\begin{array}{l}\text { In this } \\
\text { work }\end{array}$} \\
\hline & $\mathrm{RhB}^{b}$ & $\mathrm{C}($ Catal. $)=0.1 \mathrm{~g} \mathrm{~L}^{-1}, \mathrm{C}\left(\mathrm{H}_{2} \mathrm{O}_{2}\right)=15 \mathrm{mM}, \mathrm{C}\left(\mathrm{NaHCO}_{3}\right)=10 \mathrm{mM}$ & $>90 \%, 30 \mathrm{~min}$ & \\
\hline
\end{tabular}

${ }^{a}$ A fixed-bed reactor. ${ }^{b}$ LED illumination.

recovery. In order to find a suitable substitute for homogeneous catalysts, one current method involved using heterogeneous catalysts. For example, diatomite-supported cobalt, ${ }^{21} \mathrm{CoMgAl}-$ $\mathrm{Na}-\mathrm{Y},{ }^{22}$ and $\mathrm{S} / \mathrm{CoFe}_{2} \mathrm{O}_{4}$ (ref. ${ }^{23}$ ) have been applied for removing organic pollutants; however, these options also faced problems, such as their cost and complex preparation. Importantly, leaching of metal ions from these heterogeneous catalysts was inevitable and caused secondary contamination. These factors constituted the main challenges that must be overcome to allow their industrial application. Relative to such heterogeneous variants, the $\mathrm{HCO}_{3}{ }^{-}-\mathrm{H}_{2} \mathrm{O}_{2}-\mathrm{O} / \mathrm{g}-\mathrm{C}_{3} \mathrm{~N}_{4}$ catalytic system was green, inexpensive, and easy to operate. These advantages confirmed that the novel technology presented herein represented high potential for practical applications in the removal of organic pollutants from wastewater.

3.2.2. The mechanism of organic pollutant removal. To identify whether various ROS were produced in the system containing $\mathrm{HCO}_{3}{ }^{-}$and $\mathrm{H}_{2} \mathrm{O}_{2}$ with the $\mathrm{O} / \mathrm{g}-\mathrm{C}_{3} \mathrm{~N}_{4}$ catalyst, we attempted to detect selected ROS, including ${ }^{\circ} \mathrm{OH}, \mathrm{O}_{2}{ }^{\cdot-}$, and ${ }^{1} \mathrm{O}_{2}$, using different radical scavengers. ${ }^{21}$ First, a common radical scavenger for ${ }^{\circ} \mathrm{OH}$, ascorbic acid, was introduced into the reaction mixture solution. As observed in Fig. S12, $\uparrow$ addition of ascorbic acid caused the degradation rate to decrease. However, it did not completely quench the reaction, suggesting the existence of a radical-mediated degradation pathway, except for the adsorption process. Ethanol was a relatively more powerful radical scavenger, and Fig. S13 $\dagger$ displayed the influence of ethanol on RhB degradation. It is clear that the addition of ethanol significantly decreased RhB degradation, and this inhibition effect was concentration-dependent over a wide range. Therefore, we concluded that the ${ }^{\circ} \mathrm{OH}$ species was involved this reaction, but it was not the only ROS.

In order to probe the production of $\mathrm{O}_{2}{ }^{--}$along the reaction pathway, the influence of different concentrations of the scavenger, Trion, on the RhB degradation was investigated. It is clear from Fig. $\mathrm{S} 14 \uparrow$ that the RhB degradation in the presence of $5 \mathrm{mM}$ Trion decreased remarkably at first and then stabilized with increasing reaction time. This trend was also observed at higher concentrations (50 and $200 \mathrm{mM}$ ) of Trion. These results suggested that the $\mathrm{O}_{2}{ }^{\cdot-}$ radical was an important ROS. Another radical scavenger, benzoquinone, was also studied in this reaction, and the results were shown in Fig. S15. $\dagger$ It is determined that the degradation of RhB decreased with the addition of 3 and $6 \mathrm{mM}$ of benzoquinone, respectively. This confirmed that the $\mathrm{O}_{2}{ }^{--}$radical had an important role in the removal of organic pollutants in this system.

Fig. S16 $\uparrow$ shows the effect of different concentrations of $\mathrm{NaN}_{3}$ (used for singlet oxygen detection) on the RhB degradation. In this case, the change toward the RhB degradation was not significance at two different $\mathrm{NaN}_{3}$ concentrations (4 and 10 $\mathrm{mM}$ ). Therefore, we determined that ${ }^{1} \mathrm{O}_{2}$ was not a major ROS in this degradation mechanism. In order to support this conclusion, another experiment was carried out by adding furfuryl alcohol (FFA), rather than $\mathrm{NaN}_{3}$, into the reaction, and the results were shown in Fig. S17. $\dagger$ Under these conditions, the

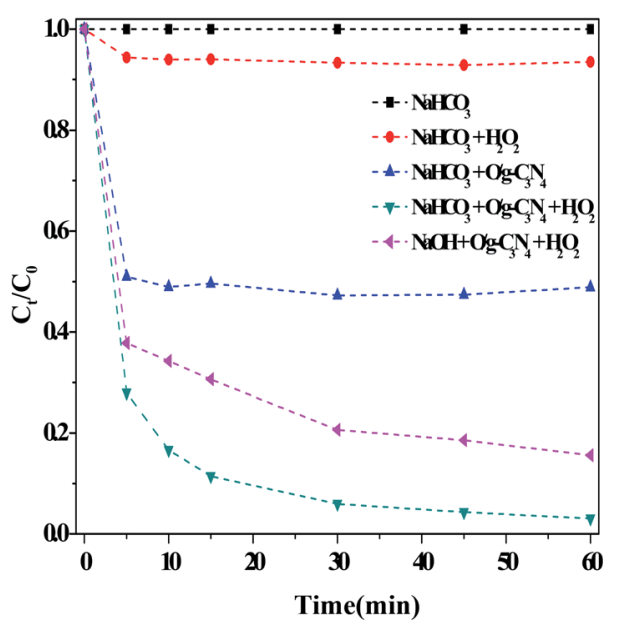

Fig. 7 Comparison results of different catalysts on the RhB degradation. Reaction conditions: $\left[\mathrm{NaHCO}_{3}\right]=10 \mathrm{mM},\left[\mathrm{H}_{2} \mathrm{O}_{2}\right]=15 \mathrm{mM},[\mathrm{O} / \mathrm{g}$ $\left.\mathrm{C}_{3} \mathrm{~N}_{4}\right]=0.8 \mathrm{~g} \mathrm{~L}^{-1},[\mathrm{RhB}]=10 \mathrm{mg} \mathrm{L}^{-1}, 25^{\circ} \mathrm{C}, \mathrm{pH} \approx 8.4$ and $60 \mathrm{~min}$. 
RhB degradation decreased only slightly relative to that of the control experiment. This fact confirmed that ${ }^{1} \mathrm{O}_{2}$ was not a primary participant in this reaction, and it was consistent with the analysis of Fig. S6. $\uparrow$ Overall, the mechanistic analysis indicated that ${ }^{\circ} \mathrm{OH}$ and $\mathrm{O}_{2}{ }^{\cdot-}$ radicals were important ROS for this reactivity, but the ${ }^{1} \mathrm{O}_{2}$ species was little involved.

3.2.3. The synergistic effect between adsorption and chemical oxidation. To fully understand the contributions of the adsorption process and ROS production, several important factors were investigated under the dark conditions, and the results were presented in Fig. 7. It is clear that $\mathrm{HCO}_{3}{ }^{-}$alone was hardly capable of degrading $\mathrm{RhB}$, and the degradation of $\mathrm{RhB}$ was extremely low even after treating with a $10 \mathrm{mM} \mathrm{HCO}_{3}{ }^{-}$ solution in the presence of $\mathrm{H}_{2} \mathrm{O}_{2}$. This finding contradicted several previous reports, ${ }^{2-11}$ likely due to the different types of organic pollutants used in the experiments and the conditions of use for $\mathrm{HCO}_{3}{ }^{-}$and $\mathrm{H}_{2} \mathrm{O}_{2}$. For examples, in previous studies, ${ }^{5,8-11}$ the organic pollutants were directly degraded by activating $\mathrm{H}_{2} \mathrm{O}_{2}$, which required a high concentration of $\mathrm{HCO}_{3}{ }^{-}$ (i.e., $500 \mathrm{mM}$ ). In general, these systems exhibited lower degradation if small $\mathrm{HCO}_{3}{ }^{-}$and $\mathrm{H}_{2} \mathrm{O}_{2}$ concentrations were incorporated; however, Kan et al. ${ }^{\mathbf{1 1}}$ discovered that the acid orange II was effectively degraded using low concentrations of $\mathrm{HCO}_{3}{ }^{-}$and $\mathrm{H}_{2} \mathrm{O}_{2}$. According to the literature, ${ }^{25}\left[\mathrm{HCO}_{4}{ }^{-}\right]_{e}=$ $K_{\text {eq }}\left\{\left[\mathrm{HCO}_{3}{ }^{-}\right]_{0} \cdot\left[\mathrm{H}_{2} \mathrm{O}_{2}\right]_{0}\right\} /\left\{1+K_{\mathrm{eq}}\left[\mathrm{HCO}_{3}{ }^{-}\right]_{0}\right\}$, where $K_{\mathrm{eq}}=0.33 \mathrm{M}^{-1}$ at $25{ }^{\circ} \mathrm{C}$, and the calculated $\left[\mathrm{HCO}_{4}{ }^{-}\right]_{\mathrm{e}}$ was approximately $49 \mu \mathrm{M}$. This concentration was about two times that of RhB, and this anion had strong oxidizing ability,,$^{\mathbf{3 , 8 2 1}}$ despite a slow reaction rate. This indicated that the $\mathrm{HCO}_{4}{ }^{-}$species was not active in this reaction (eqn (10)), consistent with literature precedent. ${ }^{19}$

$$
\mathrm{HCO}_{3}{ }^{-}+\mathrm{H}_{2} \mathrm{O}_{2} \leftrightarrow \mathrm{HCO}_{4}^{-}+\mathrm{H}_{2} \mathrm{O}
$$

The activated pathway, comprised of $\mathrm{HCO}_{3}{ }^{-}+\mathrm{H}_{2} \mathrm{O}_{2}+\mathrm{O} / \mathrm{g}$ $\mathrm{C}_{3} \mathrm{~N}_{4}$, demonstrated an increased degradation efficiency $(>90 \%$ after $60 \mathrm{~min})$. As reported previously, ${ }^{37}$ the electrons near nitrogen defect sites could elongate the $\mathrm{O}-\mathrm{O}$ bonds in $\mathrm{H}_{2} \mathrm{O}_{2}$ molecules, thereby reducing the activation energy. We have already demonstrated that the $\mathrm{O} / \mathrm{g}-\mathrm{C}_{3} \mathrm{~N}_{4}$ catalyst contained many such defect sites, which could directly activate $\mathrm{H}_{2} \mathrm{O}_{2}$ in the dark (Fig. S5 $\dagger$ ). As a result, some ROS, including ${ }^{\circ} \mathrm{OH}$ radicals, were generated and served to enhance $\mathrm{RhB}$ degradation. ${ }^{34}$ Similarly, the addition of $\mathrm{NaOH}$ rather than $\mathrm{NaHCO}_{3}$ into the reaction solution generated a similar $\mathrm{pH}$ environment $(\sim 8.4)$ and enhanced the degradation of $\mathrm{RhB}$, although not as much as $\mathrm{HCO}_{3}{ }^{-}$. In addition, the $\sim 50 \%$ enhancement in degradation efficiency over $\mathrm{O} / \mathrm{g}-\mathrm{C}_{3} \mathrm{~N}_{4}$ was obtained due to $\mathrm{HCO}_{3}{ }^{-}$, and this increase was mainly attributed to the adsorption aspect.

Overall, there are two main reasons for the enhancement exhibited by this system. The first involved the extremely high specific surface area of the $\mathrm{O} / \mathrm{g}-\mathrm{C}_{3} \mathrm{~N}_{4}$ catalyst, which was beneficial for improving the removal of RhB via an adsorption process. In theory, the $\mathrm{p} K_{\mathrm{a}}$ of $\mathrm{g}-\mathrm{C}_{3} \mathrm{~N}_{4}$ obtained from melamine was about $3,^{38}$ meaning that it could easily combine with $\mathrm{RhB}$ through electrostatic interactions ( $\mathrm{RhB}$ was a positively charged molecule, and the surface of $\mathrm{g}-\mathrm{C}_{3} \mathrm{~N}_{4}$ presented a negative charge). The zeta potential of the catalyst was determined at $\mathrm{pH} \approx 8.4$, and this value was about $-19 \mathrm{mV}$. In general, the specific surface area of the catalyst was high, so its adsorption capacity for RhB was large; consequently, the enhanced degradation was attributed partially to the high specific surface area of the catalyst. The second reason for the enhanced activity of the developed catalytic system involved ROS production. In advanced oxidation technologies, ${ }^{\circ} \mathrm{OH}$ radicals are well-known catalytic active species for the degradation of various organic pollutants, with redox potentials in acidic and alkaline conditions of $+2.8 \mathrm{~V}$ and $+1.5 \mathrm{~V}$, respectively. ${ }^{21}$ The $\mathrm{NaOH}$ or $\mathrm{NaHCO}_{3}$ environment provided a weak alkaline medium and also served to activate $\mathrm{H}_{2} \mathrm{O}_{2}$, thus inducing the formation of more ROS. However, some ROS were produced as a result of the synergistic behavior among $\mathrm{NaHCO}_{3}$, $\mathrm{H}_{2} \mathrm{O}_{2}$, and $\mathrm{O} / \mathrm{g}-\mathrm{C}_{3} \mathrm{~N}_{4}$. As previously stated, ${ }^{21}$ the $\mathrm{CO}_{3}{ }^{-}$radicals were formed by the reaction shown as eqn (1), and these radicals may be even more effective for the degradation of organic dye molecules than ${ }^{\circ} \mathrm{OH}$ radicals. The $\mathrm{HCO}_{3}{ }^{-}$anion was often employed as scavenger to detect whether ${ }^{\circ} \mathrm{OH}$ radicals were presented in the reaction solution. However, it has been reported that $\mathrm{HCO}_{3}{ }^{-}$could accelerate the degradation of organic pollutants under certain reaction conditions, i.e., with specific catalysts or at specified concentrations..$^{\mathbf{8 1 1 - 2 7}}$ This is because the ${ }^{\circ} \mathrm{OH}$ radicals (i) had shorter lifetimes due to the potential selfcombination process, ${ }^{32}$ and (ii) could react with $\mathrm{H}_{2} \mathrm{O}_{2}$ to produce $\mathrm{O}_{2} \cdot{ }^{32}$ In contrast, $\mathrm{CO}_{3}{ }^{\cdot-}$ radicals had longer lifetimes due to coulombic repulsion. ${ }^{21}$ In fact, it has been demonstrated that $\mathrm{CO}_{3}{ }^{-}$- radicals could accelerate the degradation of organic pollutants, ${ }^{21}$ or generate other effective radicals (e.g., ${ }^{\circ} \mathrm{OOH}, \mathrm{O}_{2}{ }^{\cdot-}$ and ${ }^{1} \mathrm{O}_{2}$ ) that were active for organic pollutant degradation under different conditions (eqn (2)-(6)). ${ }^{21}$

In this work, the $\mathrm{OH}$ radicals were first generated by activating $\mathrm{H}_{2} \mathrm{O}_{2}$ at the defective sites on the $\mathrm{O} / \mathrm{g}-\mathrm{C}_{3} \mathrm{~N}_{4}$ catalyst. Some $\cdot \mathrm{OH}$ radicals left the surface of the catalyst and entered the reaction solution. As mentioned above, some of these ${ }^{\circ} \mathrm{OH}$ radicals immediately reacted with each other, thus contributing to their extremely short measured lifetimes. However, if the reaction solution contained an adequate concentration of $\mathrm{HCO}_{3}{ }^{-}$ions, the ${ }^{\circ} \mathrm{OH}$ radicals may react with $\mathrm{HCO}_{3}{ }^{-}$ions to form $\mathrm{CO}_{3}{ }^{-}$radicals. In this case, the $\mathrm{RhB}$ degradation continued, and the pollutant removal efficiency increased further. This phenomenon was evidenced by the relationship between $\mathrm{HCO}_{3}{ }^{-}$concentration and $\mathrm{RhB}$ degradation, as illustrated in Fig. 3. Based on eqn (1), the formation of $\mathrm{CO}_{3}{ }^{-}$ radicals was mainly due to the reaction between $\mathrm{HCO}_{3}{ }^{-}$and 'OH. Therefore, the increased concentrations of $\mathrm{HCO}_{3}{ }^{-}$theoretically led to increased quantities of $\mathrm{CO}_{3}{ }^{-}$radicals, thus improving RhB degradation. However, if the concentration of $\mathrm{HCO}_{3}{ }^{-}$is too high, more $\mathrm{CO}_{3}{ }^{-}$and related radicals were generated (eqn (2)-(6)), resulting in a remarkable reduction in the concentration of ${ }^{\circ} \mathrm{OH}$ radicals. These conditions led to a lesser degree of RhB degradation, and clearly, this phenomenon was not observed in the $\mathrm{NaOH}$-containing system.

Overall, the optimal RhB degradation efficiency was obtained using the $\mathrm{HCO}_{3}{ }^{-}-\mathrm{H}_{2} \mathrm{O}_{2}-\mathrm{O} / \mathrm{g}-\mathrm{C}_{3} \mathrm{~N}_{4}$ system. In this case, ROS, including ${ }^{\circ} \mathrm{OH}, \mathrm{O}_{2}{ }^{\cdot-},{ }^{1} \mathrm{O}_{2}$, and $\mathrm{CO}_{3}{ }^{--}$, attacked the organic pollutants through a chemical process, leading to the 
destruction of the RhB structure. The structural change was further confirmed based on UV-vis results, as shown in Fig. S18. $\dagger$ It is worth noting that there was a large difference in the $\mathrm{Na}^{+}$content in the $\mathrm{NaOH}$ and $\mathrm{NaHCO}_{3}$ systems (negligible $(\mu \mathrm{M})$ vs. $10 \mathrm{mM}$, respectively), and its role was not thoroughly taken into consideration. To certify this assumption, preliminary experiments were conducted using $\mathrm{Na}-\mathrm{O} / \mathrm{g}-\mathrm{C}_{3} \mathrm{~N}_{4}$ as the catalyst, and the results were displayed in Fig. S19, $\dagger$ clearly showing that there was little influence on the removal of RhB.

In summary, the high degradation capability of the $\mathrm{HCO}_{3}{ }^{-}$ $\mathrm{H}_{2} \mathrm{O}_{2}-\mathrm{O} / \mathrm{g}-\mathrm{C}_{3} \mathrm{~N}_{4}$ system was mainly ascribed to the synergistic effect between adsorption and chemical oxidation. The $\mathrm{HCO}_{3}{ }^{-}$ and $\mathrm{O} / \mathrm{g}-\mathrm{C}_{3} \mathrm{~N}_{4}$ components were responsible for activating $\mathrm{H}_{2} \mathrm{O}_{2}$ and removing RhB. Specifically, the $\mathrm{O} / \mathrm{g}-\mathrm{C}_{3} \mathrm{~N}_{4}$ catalyst acted as a bifunctional material for dispelling $\mathrm{RhB}$, thus contributing to the simultaneous adsorption and chemical oxidation processes. The huge specific surface area of the $\mathrm{O} / \mathrm{g}-\mathrm{C}_{3} \mathrm{~N}_{4}$ catalyst allowed significant adsorption via a non-radical pathway, but the chemical oxidation was carried out through a radical route, which relied on the defective sites of $\mathrm{O} / \mathrm{g}-\mathrm{C}_{3} \mathrm{~N}_{4}$ for activating $\mathrm{H}_{2} \mathrm{O}_{2}$ to ROS in the presence of $\mathrm{HCO}_{3}{ }^{-}$. Chemical oxidation also occurred in the reaction solution itself, and this mechanistic pathway was outlined in Scheme 1.

3.2.4. The relationship between the catalyst's structure and its catalytic activity. To firmly establish the relationship between the structure of the catalyst and its ability to degrade $\mathrm{RhB}$, the effect of the calcination temperature when preparing $\mathrm{O} / \mathrm{g}-\mathrm{C}_{3} \mathrm{~N}_{4}-T$ was investigated. It is known that the calcination temperature influenced the specific surface area and defective sites of the resulting $\mathrm{O} / \mathrm{g}-\mathrm{C}_{3} \mathrm{~N}_{4}$. Fig. $\mathrm{S} 20 \dagger$ illustrated the effect of the calcination temperature across the series of $\mathrm{O} / \mathrm{g}-\mathrm{C}_{3} \mathrm{~N}_{4}-T$ catalysts on their $\mathrm{RhB}$ degradation performances. The $\mathrm{O} / \mathrm{g}$ $\mathrm{C}_{3} \mathrm{~N}_{4}-550$ catalyst exhibited the maximum $\mathrm{RhB}$ degradation efficiency among all variants tested under identical conditions; the catalysts prepared with lower calcination temperatures demonstrated less RhB degradation efficiency (especially below $450{ }^{\circ} \mathrm{C}$ ). This behavior was likely due to their relatively lower specific surface areas and intact polymerization. Additionally, a higher calcination temperature induced a tremendous change to the $\mathrm{g}-\mathrm{C}_{3} \mathrm{~N}_{4}$ structure, particularly at $550{ }^{\circ} \mathrm{C}$. In general, the higher the calcination temperature is employed, the greater the separation between nanosheets of $\mathrm{g}-\mathrm{C}_{3} \mathrm{~N}_{4}$ is happened. It can also easily decompose to generate small gaseous products,

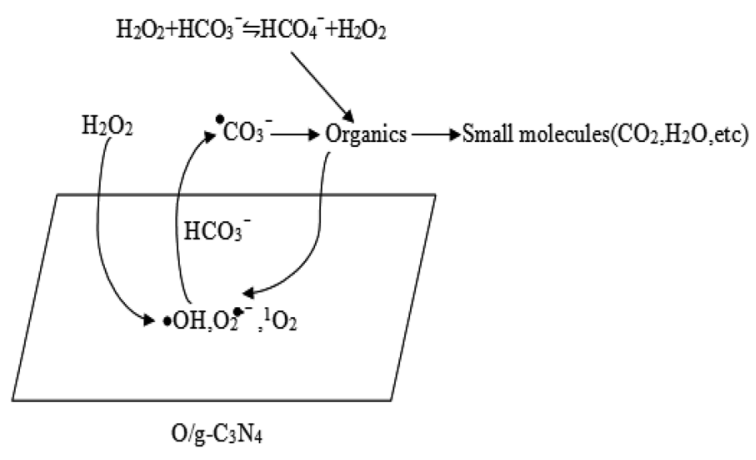

Scheme 1 The degradation pathway of organic pollutants. which diffuse between the layers of nanosheets. In this case, the morphology of the catalyst is greatly altered, leading to a higher specific surface area, as confirmed by SEM and TEM characterizations. Simultaneously, numerous defect sites, such as vacancies and edges, are generated. The resulting increased specific surface area is favorable for molecular adsorption, because it offers more catalytic active sites (the defect sites can activate $\mathrm{H}_{2} \mathrm{O}_{2}$ toward ROS in situ). ${ }^{39-44}$ However, no interesting products are obtained if the calcination temperature is too high $\left(>550{ }^{\circ} \mathrm{C}\right)$. To test this hypothesis, the relationships between the $\mathrm{S}_{\mathrm{BET}}$, the content and ratio of $\mathrm{N}\left(\mathrm{sp}^{2}\right)$ and $\mathrm{N}\left(\mathrm{sp}^{3}\right)$ (denoted as defect sites), and the catalytic activity were evaluated, and the results were compiled in Table 1 and $S 2 . \dagger$ The $S_{\text {BET }}$ increased gradually with applied temperatures below $550{ }^{\circ} \mathrm{C}$ and then significantly improved at $550{ }^{\circ} \mathrm{C}$, clearly indicating that the $S_{\mathrm{BET}}$ was closely related to the catalytic activity. Accordingly, increasing the $S_{\mathrm{BET}}$ of the catalyst led to increased RhB degradation. Meanwhile, the $\mathrm{N}\left(\mathrm{sp}^{2}\right)$ and $\mathrm{N}\left(\mathrm{sp}^{3}\right)$ ratio first increased, when changing from $350{ }^{\circ} \mathrm{C}$ to $450{ }^{\circ} \mathrm{C}$, but then began to decrease at $550{ }^{\circ} \mathrm{C}$. This behavior suggested that the defect sites corresponding to $\mathrm{N}\left(\mathrm{sp}^{3}\right)$ can to some extent act as catalytic active sites. Combined with the analysis of the degradation efficiency, we concluded that the $S_{\mathrm{BET}}$ and the defective sites from $\mathrm{N}\left(\mathrm{sp}^{3}\right)$ were two important factors for enhancing the catalytic activity of the developed system.

\section{Conclusions}

This report discussed a newly-developed strategy for treating wastewater polluted with organic contaminants. The employed system consisted of $\mathrm{HCO}_{3}{ }^{-}, \mathrm{H}_{2} \mathrm{O}_{2}$, and an $\mathrm{O} / \mathrm{g}-\mathrm{C}_{3} \mathrm{~N}_{4}$ catalyst, which together demonstrated efficient degradation of organic compounds. Various influencing factors were investigated, and the reaction conditions were optimized in terms of the catalyst loading and preparation, concentrations of $\mathrm{HCO}_{3}{ }^{-}$and $\mathrm{H}_{2} \mathrm{O}_{2}$, and light $v s$. dark operation. The catalytic system retained high stability and exhibited sufficient reproducibility after running several reaction cycles. Mechanistic probing revealed that the degradation pathway was dominated by the synergistic effect between adsorption and chemical oxidation processes. The adsorption was closely related to the tunable specific surface area of the catalyst, and the chemical oxidation was achieved by various ROS. Overall, this work presented a novel, widelyapplicable method for removing organic pollutants from wastewater.

\section{Conflicts of interest}

There are no conflicts to declare.

\section{Acknowledgements}

This work was financially supported by the National Natural Science Foundation of China (No. 51978648), Open Project of State Key Laboratory of Safety and Health for Metal Mines (No. 2019-JSKSSYS-04), Hunan Environmental Protection Scientific Research (No. Hunan Finance and construction (2019)0011), 
Open Project of Program of Provincial Key Laboratory of Clean Energy Material, LongYan University (No. QJNY-201802), China Postdoctoral Science Foundation (No. 2019M660824) and Hunan Provincial Natural Science Foundation of China (No. 2018JJ3427).

\section{References}

$1 \mathrm{~J}$. Ali, Z. Chen and G. Yin, Bicarbonate activation of hydrogen peroxide: A new emerging technology for wastewater treatment, Chin. J. Catal., 2016, 37, 810-825.

$2 \mathrm{H}$. Yao and D. E. Richardson, Epoxidation of alkenes with bicarbonate-activated hydrogen peroxide, J. Am. Chem. Soc., 2000, 122, 3220-3221.

3 D. E. Richardson, H. Yao, K. M. Frank and A. Deon, Bennett Equilibria, kinetics, and mechanism in the bicarbonate activation of hydrogen peroxide: oxidation of sulfides by peroxymonocarbonate, J. Am. Chem. Soc., 2000, 122, 17291739.

$4 \mathrm{H}$. Yao and D. E. Richardson, Bicarbonate surfoxidants: micellar oxidations of aryl sulfides with bicarbonateactivated hydrogen peroxide, J. Am. Chem. Soc., 2003, 125, 6211-6221.

$5 \mathrm{~A} . \mathrm{Xu}, \mathrm{X} . \mathrm{Li}, \mathrm{H}$. Xiong and G. Yin, Efficient degradation of organic pollutants in aqueous solution with bicarbonateactivated hydrogen peroxide, Chemosphere, 2011, 82, 11901195.

6 J. Wu, H. Xiao, T. Wang, T. Hong, B. Fu, D. Bai, Z. He, S. Peng, X. Xing, J. Hu, Pu Guo and X. Zhou, N6Hydroperoxymethyladenosine: a new intermediate of chemical oxidation of N6-methyladenosine mediated by bicarbonate-activated hydrogen peroxide, Chem. Sci., 2015, 6, 3013-3017.

7 M. Puiu, T. Galaon, L. Bondilă, A. Răducan and O. Dumitru, Feed-back action of nitrite in the oxidation of nitrophenols by bicarbonate-activated peroxide system, Appl. Catal., A, 2016, 516, 90-99.

8 D. Alok, Bokare, Wonyong Choi. Bicarbonate-induced activation of $\mathrm{H}_{2} \mathrm{O}_{2}$ for metal-free oxidative desulfurization, J. Hazard. Mater., 2016, 304, 313-319.

$9 \mathrm{H}$. Fakhraian and F. Valizadeh, Activation of hydrogen peroxide via bicarbonate, sulfate, phosphate and urea in the oxidation of methyl phenyl sulfide, J. Mol. Catal. A: Chem., 2010, 333, 69-72.

10 S. Zhao, H. Xi, Y. Zuo, Qi Wang, Z. Wang and Z. Yan, Bicarbonate-activated hydrogen peroxide and efficient decontamination of toxic sulfur mustard and nerve gas simulants, J. Hazard. Mater., 2018, 344, 136-145.

11 H. Kan, S. Heng, Z. Yang, R. Wu, J. Shen, G. Qu and T. Wang, Purification of dye wastewater using bicarbonate activated hydrogen peroxide: reaction process and mechanisms, Sep. Purif. Technol., 2020, 232, 115974.

12 S.-X. Liang, Li-X. Zhao, Bo-T. Zhang and J.-M. Lin, Experimental studies on the Chemiluminescence reaction mechanism of carbonate/bicarbonate and hydrogen peroxide in the presence of cobalt (II), J. Phys. Chem. A, 2008, 112, 618-623.
13 A. Xu, X. Li, S. Ye, G. Yin and Q. Zeng, Catalyzed oxidative degradation of methylene blue by in situ generated cobalt (II)-bicarbonate complexes with hydrogen peroxide, Appl. Catal., B, 2011, 102, 37-43.

14 X. Li, Z. Xiong, X. Ruan, D. Xia, Q. Zeng and A. Xu, Kinetics and mechanism of organic pollutants degradation with cobalt-bicarbonate-hydrogen peroxide system: Investigation of the role of substrates, Appl. Catal., A, 2012, 411-412, 2430 .

15 X. Long, Z. Yang, H. Wang, M. Chen, K. Peng, Q. Zeng and A. Xu, Selective degradation of orange II with the cobalt(II)bicarbonate-hydrogen peroxide system, Ind. Eng. Chem. Res., 2012, 51, 11998-12003.

16 Z. Yang, H. Wang, M. Chen, M. Luo, D. Xia, A. Xu and Q. Zeng, Fast Degradation and biodegradability improvement of reactive brilliant red $\mathrm{X}-3 \mathrm{~B}$ by the cobalt(II)/bicarbonate/hydrogen peroxide system, Ind. Eng. Chem. Res., 2012, 51, 11104-11111.

17 M. Luo, L. Lv, G. Deng, Y. Wen, R. Yang, X. Li and A. Xu, The mechanism of bound hydroxyl radical formation and degradation pathway of acid orange II in Fenton-like $\mathrm{Co}^{2+}$ $\mathrm{HCO}_{3}{ }^{-}$system, Appl. Catal., A, 2014, 469, 198-205.

18 I. F. Macías-Quiroga, E. F. Rojas-Méndez, G. I. GiraldoGómez and N. R. Sanabria-González, Experimental data of a catalytic decolorization of Ponceau $4 \mathrm{R}$ dye using the cobalt(II) $/ \mathrm{NaHCO}_{3} / \mathrm{H}_{2} \mathrm{O}_{2}$ system in aqueous solution, Data Brief, 2020, 30, 105463.

19 L. Cheng, M. Wei, L. Huang, F. Pan, D. Xia, X. Li and A. Xu, Efficient $\mathrm{H}_{2} \mathrm{O}_{2}$ oxidation of organic dyes catalyzed by simple copper(II) ions in bicarbonate aqueous solution, Ind. Eng. Chem. Res., 2014, 53, 3478-3485.

20 J. Peng, H. Shi, J. Li, L. Wang, Z. Wang and S. Gao, Bicarbonate enhanced removal of triclosan by copper(II) catalyzed Fenton-like reaction in aqueous solution, Chem. Eng. J., 2016, 306, 484-491.

21 Li Zhou, W. Song, Z. Chen and G. Yin, Degradation of organic pollutants in wastewater by bicarbonate-activated hydrogen peroxide with a supported cobalt catalyst, Environ. Sci. Technol., 2013, 47, 3833-3839.

22 J. Ali, Y. Li, X. Lu, Z. Chen, W. Liu and G. Yin, Controlled leaching with prolonged activity for Co-LDH supported catalyst during treatment of organic dyes using bicarbonate activation of hydrogen peroxide, J. Hazard. Mater., 2015, 289, 165-173.

23 X. Guo, H. Li and S. Zhao, Fast degradation of acid orange II by bicarbonate-activated hydrogen peroxide with a magnetic S-modified $\mathrm{CoFe}_{2} \mathrm{O}_{4}$ catalyst, J. Taiwan Inst. Chem. Eng., 2015, 55, 90-100.

24 L. Duan, Y. Chen, K. Zhang, H. Luo, J. Huang and A. Xu, Catalytic degradation of acid orange 7 with hydrogen peroxide using $\mathrm{Co}_{\mathrm{x}} \mathrm{O}_{\mathrm{y}}-\mathrm{N} / \mathrm{GAC}$ catalysts in a bicarbonate aqueous solution, $R S C A d v ., 2015$, 5, 84303-84310.

25 P. Liu, N. Yang, W. Han, W. Xiao, D. Wang, Y. Xiong, M. Zhou, H. Hou and X. Mao, Heterogeneous activation of peroxymonocarbonate by Co-Mn oxides for the efficient degradation of chlorophenols in the presence of 
a naturally occurring level of bicarbonate, Chem. Eng. J., 2018, 334, 1297-1308.

26 Y. Li, J. Ali, A. Khan, X. Lu, Z. Chen, W. Liu and G. Yin, Synergistic degradation of phenols by bimetallic CuO$\mathrm{Co}_{3} \mathrm{O}_{4} @ \gamma-\mathrm{Al}_{2} \mathrm{O}_{3}$ catalyst in $\mathrm{H}_{2} \mathrm{O}_{2} / \mathrm{HCO}_{3}{ }^{-}$system, Chin. J. Catal., 2016, 37, 963-970.

27 J. Ali, Y. Li, L. Guo, A. Khan, Z. Chen, J. Wang, J. Yang, W. Liu and G. Yin, Bimetallic synergistic degradation of chlorophenols by $\mathrm{CuCoO}_{\mathrm{x}}-\mathrm{LDH}$ catalyst in bicarbonateactivated hydrogen peroxide system, $R S C A d v$., 2016, 6, 72643-72653.

28 L. Yang, C. Chuh-Shun, Y.-J. Tu, Y.-H. Huang and H. Zhang, Heterogeneous degradation of organic pollutants by persulfate activated by $\mathrm{CuO}-\mathrm{Fe}_{3} \mathrm{O}_{4}$ : mechanism, stability, and effects of $\mathrm{pH}$ and bicarbonate ions, Environ. Sci. Technol., 2015, 49, 6838-6845.

29 C. Pétrier, R. Torres-Palma, E. Combet, G. Sarantakos, S. Baup and C. Pulgarin, Enhanced sonochemical degradation of bisphenol-A by bicarbonate ions, Ultrason. Sonochem., 2010, 17, 111-115.

$30 \mathrm{~W}$. Hu, S. Chen, D. Wu, J. Zheng and X. Ye, Ultrasonicassisted citrus pectin modification in the bicarbonateactivated hydrogen peroxide system: Chemical and microstructural analysis, Ultrason. Sonochem., 2019, 58, 104576.

31 D. Wu, S. Hu, H. Xue, X. Hou, H. Du, G. Xu and Y. Yuan, Protonation and microwave-assisted heating induced excitation of lone-pair electrons in graphitic carbon nitride for increased photocatalytic hydrogen generation, J. Mater. Chem. A, 2019, 7, 20223-20228.

32 Y. Cui, Z. Ding, P. Liu, M. Antonietti, X. Fu and X. Wang, Metal-free activation of $\mathrm{H}_{2} \mathrm{O}_{2}$ by $\mathrm{g}-\mathrm{C}_{3} \mathrm{~N}_{4}$ under visible light irradiation for the degradation of organic pollutants, Phys. Chem. Chem. Phys., 2012, 14, 1455-1462.

$33 \mathrm{Hu}$, D. Jiang, L. Gu, G. Xu, Z. Li and Y. Yuan, Awakening $\mathrm{n} \rightarrow$ $\pi^{*}$ electronic transition by breaking hydrogen bonds in graphitic carbon nitride for increased photocatalytic hydrogen generation, Chem. Eng. J., 2020, 399, 125847.

34 T.-J. Jiang, C.-W. Luo, C. Xie, Y.-H. Wei and Li An, Synthesis of oxygen-doped graphitic carbon nitride and its application for the degradation of organic pollutants via dark Fentonlike reactions, $R S C$ Adv., 2020, 10, 32906-32918.

35 Y. Liu, X. He, X. Duan, Y. Fu, D. Fatta-Kassinos and D. D. Dionysios, Significant role of UV and carbonate radical on the degradation of oxytetracycline in UV-AOPs: Kinetics and mechanism, Water Res., 2016, 95, 195-204.

36 Y. Huang, M. Kong, D. Westerman, E. G. Xu, C. Scott, K. H. Cochran, Y. Liu, S. D. Richardson, D. Schlenk and D. D. Dionysios, Effects of $\mathrm{HCO}_{3}{ }^{-}$on degradation of toxic contaminants of emerging concern by $\mathrm{UV} / \mathrm{NO}_{3}{ }^{-}$, Environ. Sci. Technol., 2018, 52, 12697-12707.

37 S. Zhang, Y. Liu, P. Gu, R. Ma, T. Wen, G. Zhao, L. Li, Y. Ai, C. $\mathrm{Hu}$ and $\mathrm{X}$. Wang, Enhanced photodegradation of toxic organic pollutants using dual-oxygen doped porous $g-\mathrm{C}_{3} \mathrm{~N}_{4}$ : Mechanism exploration from both experimental and DFT studies, Appl. Catal., B, 2019, 248, 1-10.

38 W. Fang, J. Liu, Yu Lei, Z. Jiang and W. Shangguan, Novel (Na, O) co-doped $\mathrm{g}-\mathrm{C}_{3} \mathrm{~N}_{4}$ with simultaneously enhanced absorption and narrowed bandgap for highly efficient hydrogen evolution, Appl. Catal., B, 2017, 209, 631-636.

39 Ai-Y. Zhang, L. Tan, Y.-Y. He and Y.-X. Mou, Heterogeneous activation of $\mathrm{H}_{2} \mathrm{O}_{2}$ by defect-engineered $\mathrm{TiO}_{2-\mathrm{x}}$ single crystals for refractory pollutants degradation: A Fenton-like mechanism, J. Hazard. Mater., 2016, 3115, 81-90.

40 N. Zhang, E. P. Tsang, J. Chen, Z. Fang and D. Zhao, Critical role of oxygen vacancies in heterogeneous Fenton oxidation over ceria-based catalysts, J. Colloid Interface Sci., 2020, 558, 163-172.

41 P. Gao, X. Chen, H. Mengjie, F. Xiao and S. Yang, Oxygen vacancy enhancing the $\mathrm{Fe}_{2} \mathrm{O}_{3}-\mathrm{CeO}_{2}$ catalysts in Fenton-like reaction for the sulfamerazine degradation under $\mathrm{O}_{2}$ atmosphere, Chemosphere, 2019, 228, 521-527.

42 Q. Xia, Z. Yao, D. Zhang, D. Li, Z. Zhang and Z. Jiang, Rational synthesis of micronano dendritic $\mathrm{ZVI} @ \mathrm{Fe}_{3} \mathrm{O}_{4}$ modified with carbon quantum dots and oxygen vacancies for accelerating Fenton-like oxidation, Sci. Total Environ., 2019, 671, 1056-1065.

43 Xi Xiao, T. T. Hu, Bo Meng, Y. Sun and Yi-F. Han, Catalytic degradation of anthraquinones-containing $\mathrm{H}_{2} \mathrm{O}_{2}$ production effluent over layered $\mathrm{Co}-\mathrm{Cu}$ hydroxides: defects facilitating hydroxyl radicals generation, Appl. Catal., B, 2020, 260, 118157.

44 S. Song, H. Yang, R. Rao, H. Liu and A. Zhang, Defects of multi-walled carbon nanotubes as active sites for benzene hydroxylation to phenol in the presence of $\mathrm{H}_{2} \mathrm{O}_{2}$, Catal. Commun., 2010, 11, 783-787. 